\title{
ANALISIS PELAYANAN CS ( CUSTOMER SERVICE ) TERHADAP KEPUASAN NASABAH PADA BANK DANAMON DI SUKODADI LAMONGAN
}

\author{
*(Yunni Rusmawati DJ, Bhiaztika Ristyanadi \\ Fakultas Ekonomi Universitas Islam Lamongan. \\ yunnirusmawatidj@gmail.com,bhiaznya_nadi@yahoo.com
}

\begin{abstract}
ABSTRAK
Penelitian ini bertujuan untuk menganalisis pengaruh dimensi kualitas pelayanan yang terdiri dari reliability, resposivines, tangible, assurance, emphaty, terhadap kepuasan nasabah, secara simultan maupun parsial dan untuk mengetahui dimensi kualitas pelayanan manakah yang paling dominan berpengaruh terhadap kepuasan nasabah pada Bank Danamon Sukodadi. Penelitian ini bersifat kuantitatif dengan jumlah sampel 98 responden. Hasil penelitian ini menunjukan bahwa dengan signifikasi 5\% secara simultan dimensi pelayanan CS berpengaruh signifikan terhadap kepuasan nasabah dengan nilai signifikasi 0,000 dan $F_{\text {hitung }}$ sebesar 194,656. Secara parsial indikator reliabilithy berpengaruh signifikan dengan hasil signifikasi 0,000 dan $t_{\text {hitung }} 11,821$, responsiviness berpengaruh signifikan dengan hasil signifikasi 0,000 dan $t_{\text {hitung }}$ 15,018,tangiable berpengaruh signifikan dengan hasil signifikasi 0,000 dan $t_{\text {hitung }}$ 6,608,assurance berpengaruh signifikan dengan hasil signifikasi 0,002 dan $t_{\text {hitung }} 3,147$,empathy berpengaruh signifikan dengan hasil signifikasi 0,000 dan $t_{\text {hitung }}$ 4,533. Kesimpulan dari penelitian ini menunjukan bahwa semua dimensi pelayanan CS berpengaruh secara simultan dan parsial terhadap kepuasan nasabah di Bank Danamon Sukodadi Lamongan, adapun dimensi pelayanan CS yang paling dominan berpengaruh adalah Responsiviness.
\end{abstract}

Kata kunci : Pelayanan Customer Service, Kualitas Pelayanan Customer Service, dan Kepuasan Nasabah

\section{PENDAHULUAN}

Perbankan merupakan salah satu badan usaha dalam bidang pelayanan jasa keuangan. Fungsi bank merupakan perantara di antara masyarakat yang membutuhkan dana dengan masyarakat yang kelebihan dana, di samping menyediakan jasa jasa perbankan lainnya. Dalam dunia perbankan terdapat manajemen sumber daya manusia yang menjadi sorotan maupun tumpuan bagi sebuah lembaga keuangan untuk tetap dapat bertahan. Sumber daya manusia memiliki peran utama dalam suatu kegiatan organisasi dan sumber daya paling penting untuk memenangkan persaingan.

Persaingan bisnis didunia perbankan menjadi sangat ketat kecenderungan itu terlihat diantaranya dengan semakin banyaknya bank-bank mengadakan promosi besar-besaran kepada nasabah. Perbankan akan terus berupaya meraih dana dari masyarakat dalam bentuk tabungan dan giro dengan demikian kompetisi perbankaan akan semakin bersaing. 
Kualitas pelayanan menjadi faktor yang sangat penting bagi nasabah, untuk menentukan apakah nasabah akan puas ataukah tidak puas terhadap sistem pelayanan yang diberikan oleh Bank itu sendiri Peningkatan pelayanan kepada para nasabah adalah hal yang sangat penting dalam usaha meningkatkan kepuasan nasabah, karena nasabah sangat besar peranannya dalam pendapatan sebuah bank, hal ini secara langsung maupun tidak langsung berpengaruh terhadap eksistensi perbankan itu sendiri. Setiap bank memiliki masing-masing strategi dalam hal pelayanan nasabah, dengan memberikan pelayanan yang terbaik tentunya nasabah akan merasa puas atas pelayanan yang diberikan sehingga akan tetap setia menggunakan produk yang ditawarkan pihak perbankan dan pada akhirnya menjadi nasabah tetap di bank tersebut, adapun dimensi kualitas pelayanan yang diberikan menurut Wijaya ( 2011:74 ) meliputi beberapa macam kategori yaitu berupa reliability, responsiveness, tangiable, assurance ,dan juga empathy .

Salah satu bagian yang bertugas melayani para nasabah ialah Customer Service.Menurut Kasmir ( 2014:249 ) Customer Service merupakan kegiatan yang di peruntungkan atau ditunjukan untuk meningkatkan kepuasan kepada nasabah. Pada dasarnya karyawan Bank telah bekerja sesuai dengan aturan yang berlaku sesuai prosedur kinerja atau sistem pelayanan yang berlaku tetapi dalam pelayanan customer service belum sepenuhnya menunjukkan terjadinya peningkatan kepuasan.

Adapun untuk mendukung upaya meningkatkan kualitas pelayananya Bank Danamon Simpan Pinjam Sukodadi Lamongan memiliki suatu standar pelayanan yaitu sikap yang Menarik Ramah dan Bertanggung Jawab di harapakan sikap ini akan memberikan mutu pelayanan yang maksimal serta $\mathrm{Pt}$ Bank Danamon harus mengetahui faktor - faktor pelayanan dan juga karektersitik setiap nasabah agar dapat memberikan pelayanan yang baik dan memuaskan.

Bank membutuhkan karyawan yang berkualitas yang harus ada dalam manajemen baik yang berhubungan langsung dengan nasabah maupun tidak.

Berdasarkan uraian di atas dapat diketahui beberapa adanya rumusan masalah yaitu apakah dimensi pelayanan customer service yang terdiri dari reliabilithy, responsivines, tangiable, assurance, dan empathy mempunyai pengaruh secara parsial dan simultan terhadap kepuasan nasabah di Bank Danmaon Sukodadi Lamongan serta dimensi pelyanan customer service manakah yang paling dominan berpengaruh terhadap kepuasan nasabah di Bank Danamon Sukodadi Lamongan.

Tujuan dari penelitian ini adalah untuk menganalisis pengaruh dimensi kualitas pelayanan yang terdiri dari reliability, resposivines, tangible, assurance, dan emphaty, terhadap kepuasan nasabah, secara parsial maupun simultan dan untuk mengetahui dimensi kualitas pelayanan manakah yang paling dominan berpengaruh terhadap kepuasan nasabah di Bank Danamon Sukodadi Lamongan.

\section{Customer Service}

Customer Service memegang peranan sangat penting disamping memberikan pelayanan juga sebagai pembina hubungan dengan masyarakat atau public relation. Customer service bank dalam memberikan pelayanan kepada nasabah selalu berusaha menarik calon nasabah yang bersangkutan. Customer Service juga harus dapat menjaga nasabah lama agar tetap agar tetap menjadi nasabah bank. Oleh karena itu, tugas-tugas yang diemban oleh para Customer service merupakan tulang 
punggung kegiatan operasional dalam dunia perbankaan. Menurut Kasmir (2014:249 ) Secara umum, pengertian Customer Service adalah setiap kegiatan yang diperuntukan atau ditujukan untuk memberikan kepuasan kepada nasabah, melalui pelayanan yang diberikan seseorang sehingga dapat memenuhi keinginan dan kebutuhan nasabah.

Sebagai seorang Customer Service tentu telah ditetapkan fungsi dan tugas yang harus diembannya. Fungsi dan tugas-tugas Customer Service harus benar-benar dipahami sehingga seorang Customer Service dapat menjalankan tugasnya secara prima.

Adapun fungsi Customer Service menurut Kasmir (2014:250 ) adalah: Sebagai Resepsionis Customer Service berfungsi sebagai penerima tamu yang datang ke Bank, Sebagai Deskman Customer Service berfungsi sebagai orang yang melayani berbagai macam aplikasi, Sebagai Salesman Customer Service berfungsi sebagai orang yang menjual produk perbankan sekaligus sebagai pelaksana cross selling, Sebagai Customer Relation Officer Customer Service berfungsi sebagai orang yang dapat membina hubungan baik dengan seluruh nasabah, Sebagai komunikator Customer Service berfungsi sebagai orang yang menghubungi nasabah dan memberikan informasi tentang segala sesuatu yang ada hubunganya antara bank dengan nasabah.

Dasar-dasar pelayanan perlu dikuasai oleh seorang Customer Service sebelum melaksanakan tugasnya, mengigat karakter masing-masing nasabah sngat beragam. Berikut ini dasar-dasar pelayanan yang harus dipahami tersebut yakni sebagi berikut ( Kasmir,2014:252 ) : Berpakain dan berpenampilan rapi dan bersih, Percaya Diri, bersikap akrab, dan penuh senyum , Menyapa dengan lembut, Tenang, sopan , hormat serta tekun mendegarkan setiap pembicaraan, Berbicara dengan bahasa yang baik dan benar, Bergairah dalam melayani nasabah dan tunjuka kemampuanya, Jangan menyela atau memotong pembicaraan, Serta Mampu menyakini nasabah memberikan kepuasan .

\section{Pelayanan}

Menurut Tjptono \& Diana , 2003 dalam ( Wijaya, $2011: 74$ ) terdapat lima dmensi kualitas yaitu : Reliability ( kehandalan ) adalah kemmapuan memberikan pelayanan yang dijanjikan dengan akurat dan memuaskan, Responsiviness ( ketangapan atau kepedulian ) adalah keinginan para staf untuk membantu para pelanggan dan memberikan pelayanann dengan tangap dan peduli terhadap keluhan atau harapan, Assurance ( jaminan kepastian ) adalah kompetensi yang sedemikian hingga memberikan rasa aman dari bahaya, resiko, atau keraguan, dan kepastian, Empathy ( empathy = empati ) adalah sifat dan kemampuan untuk memberikan perhatian penuh kepada pelanggan,kemudahan melakukan kontak, komunikasi yang baik dan memahami kebutuhan pelanggan secara individual dan tangiable ( berwujud ) adalah wujud kenyataan secara fisik yang meliputi fasilitas, pearalatan, dan sarana informasi atau komunikasi.

\section{Kepuasan Nasabah}

Pengertian kepuasan nasabah dari berbagai ahli tidak jauh berbeda hanya tergantung dari sudut mana kita memandangnya. Menurut Kotller dalam Kasmir ( 2014:263 ) kepuasan pelanggan merupakan penilian dari pelanggan atas penggunaan barang ataupun jasa dibandingkan dengan harapan sebelum penggunanya, Kepuasaan pelanggan dalam dunia perbankaan harus diartikan secara menyeluruh jangan sepotongpotong. Artinya nasabah akan merasa 
sangat puas apabila komponen kepuasaan tersebut bisa terpenuhi secara lengkap. Berikut ini kepuasaan nasabah dalam dunia perbankaan sebagai berikut ( Kasmir, 2010:57 ) : Tangiables Merupakan bukti fisik yang harus dimiliki oleh karyawan bank, seperti gedung, perlengkapan kantor, daya tarik karyawan, saran komunikasi, dan sarana fisik lainya, Responsivitas Yaitu adanya keinginan dan kemauan karyawan bank dalam memberikan pelayanan kepada pelanggan, Assurance Adanya jaminan bahwa karyawan memiliki pengetahuan, kompetensi, kesopanan, dan sifat atau perilaku yang dapat dipercaya, Reliabilitas Yaitu kemampuan bank dalam memberikan pelayanan yang telah dijanjikan dengan cepat, akurat, serta memuaskan pelanggannya, Empati Yaitu mampu memberikan kemudahan serta menjalin hubungan dengan nasabah secara efektif.

Dalam menetukan seberapa besar kepuasan nasabah terhadap suatu bank dapat dilakukan dengan berbagai cara Menurut Kotler dalam ( Kasmir, 2014:265 ) Pengukuran kepuasan pelanggan dapat dilakuakan melalui empat sarana, yaitu sebagai berikut : Sistem keluhan dan usulan Artinya seberapa banyak keluhan atau komplain yang dilakukan nasabah dalam suatu perode. makin banyak berarti makin kurang baik, demikian pula sebaliknya, untuk itu perlu adanya sistem keluhan dan usulan, Surve kepuasan konsumen Dalam hal ini bank perlu secara berkala perlu melakukan surve, baik melalui wawancraa maupun kuesioner tentang segala sesuatu yang berhubungan dengan bank tempat nasabah melakukan transaksi selama ini, Konsumen samaran Bank dapat mengirim karyawanya atau melalui orang lain untuk berpura-pura menjadi nasabah guna melihat nasabah guna melihat pelayanan yang diberikan oleh karyawan bank secara langsung sehingga terlihat jelas bagaimana karyawan melayani nasabah yang sesugguhnya, Analisis mantan atau bekas pelanggan dengan melihat catatan nasabah yang pernah menjadi nasabah bank guna mengetahui sebab-sebab mereka tidak lagi menjadi nasabah bank kita.

\section{METODE PENELITIAN}

Penelitian ini dilakukan pada bulan Januari sampai Februari 2018, yang bertempat di Bank Danamon Sukodadi Lamongan yang berlokasikan di Jln Urip Sumaharjo No. 24 , Desa Sukodadi , Kec. Sukodadi, Kab. Lamongan, Jenis penelitian yang digunakan adalah penelitian Kuantitatif. Kuantitatif adalah jenis penelitian yang penemuan yang dapat dicapai ( diperoleh ) dengan menggunakan prosedur statistic atau cara lain dari kuantifikasi (pengukuran). (Sujarweni,2014:6)

Teknik Penarikan Sampel : Populasi merupakan keseluruhan subyek penelitan, apabila seseorang ingin meneliti semua elemen yang ada dalam wilayah penelitan maka penelitianya merupakan penelitin populasi Arikunto,(2010:173). Oleh karena itu populasi penelitian merupakan keseluruhan ( universum ) dari objek penelitian yang berupa manusia, hewan, tubuh-tumbuhan, udara, gejala, nilai, peristiwa, sikap hidup, dan sebagainya, sehingga objek-objek ini mendapat sumber data penelitian, Pada penelitian ini populasi yang digunakan adalah seluruh nasabah Bank Danamon Sukodadi Lamongan, Sampel merupakan sebagian dari populasi atau wakil populasi yang dteliti (Arikunto, 2010:174 ), jumlah sampel yang digunakan dalam penelitian ini sebanyak 98 responden, Teknik sampling yang digunakan dalam penelitian ini adalah accidental sampling sampling aksidental 
adalah metode dengan cara pengambilan sampel secara kebetulan. Anggota populasi yang secara dijumpai oleh peneliti pada saat penelitian, maka itulah menjadi sampelnya (Masyhuri, Zainudin, ( 2011:184).

Opersional variabel adalah sesuatu menunjukan alat pengambil data mana yang cocok untuk digunakan yang didasarkan atas sifat-sifat hal yang diamati atau diobservasi ( Sumandi, 2000 ) dalam Wijaya, ( 2011:138). Dalam penelitian ini definisi operasionalnya adalah : Variabel bebas atau independent variable ( $\mathrm{x}$ ) Menurut Wijaya ( 2011:129) variabel bebas adalah suatu variabel yang memepengaruhi atau menjadi penyebab perubahan pada variabel dependen atau tak bebas ( terikat ).

Variabel bebas dalam penelitian ini adalah pelayanan customer service. Adapun variabel - variabel pelayanan yang diukur adalah : Relibility (X1 )Adalah kehandalan yaitu kemampuan perusahaan untuk memberikan suatu pelayanan sesuai yang dijanjikan secara akurat dan terpercaya, Indikator yang digunakan adalah Kehandalan petugas dalam memberikan informasi pelayanan, dan kehandalan petugas dalam memudahkan teknis pelayanan, Responsiveness ( $X 2$ )Adalah kemauan untuk membantu dan memberikan pelayanan yang cepat, Indikator yang digunakan adalah Respon petugas pelayanan terhadap keluhan nasabah, dan Respon petugas pelayanan terhadap kritikan nasabah. Tangiable ( X3 ) Meliputi bukti fisik yaitu kemampuan perusahaan dalam menunjukkan eksistensinya kepada pihak eksternal. Indikator yang digunakan adalah pelayanan yang optimal dan Penampilan petugas pelayanan.. Assurance ( X4) Yaitu pengetahuan, kesopan santunan, dan kemampuan para pegawai perusahaan untuk menumbuhkan rasa percaya para pelanggan kepada perusahaan. Indikator yang digunakan adalah Kemampuan sosial petugas pelayanan dan Kemampuan adminitrasi petugas pelayanan, Empathy ( X5) Yaitu memberikan perhatian yang tulus dan bersifat individual atau pribadi. Indikator yang digunakan adalah Kepedulian Petugas dan Keramahan petugas pelayanan.

Variabel Terikat atau dependent variabel ( $\mathrm{y}$ ) Menurut Wijaya ( 2011:129 ) variabel terikat adalah variabel yang di pengaruhi atau menjadi akibat dari variabel dependen.

Metode analisis yang akan digunakan dalam memecahkan masalah yang telah dikemukakan serta untuk membuktikan hipotesis adalah sebagai berikut :Validitas Menurut Wijaya ( 2011:165 ) validitas adalah tingkat kemampuan untuk mengukapkan sesuatu yang menjadi sasaran pokok pengukuran yang dilakuakn dengan instrumen tersebut. Instrutemen yang valid atau sahih mempunyai validitas yang tinggi. Sebaliknya instrumen yang kurang valid mempunyai validitas rendah, Reliabilitas adalah uji yang digunakan untuk mengukur konsitensi jawaban responden terhadap keseluruhan item pertayaan yang diajukan.

Uji reliabilitas digunakan untuk menunjukan sejauh mana alat pengukur ( instrumen) dapat memperlihatkan kemantapan, keajengan, atau stabilitas hasil pengamatan bila diukur dengan instrumen tersebut dalam waktu berikutnya dengan kondisi tetap. Tinggi rendahnya reliabilitas secar empiris ditunjukan oleh koefisien reliabilitas yang besarnya antara 0,00 hingga 100, Uji reliabilitas dalam penelitian ini menggunakan metode Cronbach Alpha yang dibantu dengan progam SPPS.(Wijaya , 2011:165)

Uji $F$ uji simultan adalah uji statistic untuk koefisien regresi yang 
simultan atau serentak atau bersama sama mempenga ruhi variabel dependen (Y). (Silaen dan Heriyanto,2013:146).

\section{PEMBAHASAN}

Berdasarkan hasil analisis didapatkan sebagai berikut : Dari uji validitas diketahui $r$ tabel sebesar $0,198($ $\mathrm{df}=\mathrm{N}-2$ dan probabilitasnya 0,05$)$, Uji validitas indikator $\mathrm{X} 1,1=0,990, \mathrm{X} 1,2=$ 0,991 , indikator $X 2,1=0,777, X 2,2=$ 0,738 , indikator $\mathrm{X} 3,1=0,607, \mathrm{X} 3,2=$ 0,768 , indikator $X 4,1=0,5544, X 4,2=$ 0,666 , indikator $X 5,1=0,838, X 5,2=$ 0,864 sedangkan indikator $\mathrm{Y} 1=0,838$, $\mathrm{Y} 2=0,838$, Y3 $=0,540, \mathrm{Y} 4=0,496$, Y5 = 0,435 , Y6 $=0,851$, Dari hasil diatas menunjukan semua instrument valid, Hasil korelasi $r$ menunjukan semua instrumen lebih besar dari 0,198.

Dari uji reliabilitas diketahui nilai Crobach Alpha lebih besar dari 0,60, dan diketahui hasil uji reliabilitas indikator $\mathrm{X} 1=0,979, \mathrm{X} 2=0,798, \mathrm{X} 3=$ $0,734, \quad X 4=0,625, \quad X 5=0,619$, dan indikator $\mathrm{Y}=0,752$ menunjukan semua variabel mempunyai koefisien alpha yang lebih besar dari 0,60 sehingga dapat dikatakan bahwa masing-masing variabel adalah reliabel.

Dari hasil uji asumsi klasik normalitas diketahui grafik histogramnya berdistribusi normal, uji multikolenieritas menunjukan nilai VIF semua variabel bebas lebih kecil dari 10 sedangkan nilai toleransi semua variabel bebas lebih dari 0,1 atau $10 \%$, yang berarti tidak terjadi korelasi antar variabel bebas dengan demikian tidak terjadi gejala multikolenieritas, sedangkan hasil uji heteroksedastititas menunjukan pada grafik bahwa titik-titik menyebar secara acak tidak membentuk pola tertentu hal itu menunjukan tidak terjadi penyimpangan asumsi klasik heteroksedastititas.
Dari uji regresi linier berganda didapatkan suatu persamaan regresi sebagai berikut :

$\mathrm{Y}=0,743+0,902 \mathrm{X} 1+2,062 \quad \mathrm{X} 2 \quad-$ $0,907 \mathrm{X} 3+0,515 \mathrm{X} 4+0,371 \mathrm{X} 5$ artinya $\mathrm{a}=$ 0,743 merupakan konstanta yang berarti apabila variabel bebas dalam penelitian ini reliabilithy, responsiviness, tangiable, asurance dan empathy pengaruhnya $=0$, maka hasil dari kepuasan nasabah sebesar 0, 743, Sehingga dapat diuraikan bahwa variabel relaibilithy (X1) mempunyai pengaruh sebesar 0,902, variabel responsiviness (X2) mempunyai pengaruh sebesar 2,062, variabel tangiable (X3) mempunyai pengaruh sebesar -0,907, variabel assurance (X4) mempunyai pengaruh sebesar 0,515 , dan variabel empathy (X5) mempunyai pengaruh sebesar 0,371, Jadi dapat disimpulkan variabel yang paling dominan berpengaruh adalah dimensi pelayanan responsiviness (X2) karena memiliki nilai koefesien regresi tertinggi sebesar 2,062.

Dari uji koefisien determinasi dapat diketahui bahwa koefisien determinasi (Adjusted $R$ Square) yang diperoleh sebesar 0,909, hal ini berarti 90,9\% variasi variabel pelayanan CS dapat dijelaskan oleh variabel reliabilithy, responsiviness, tangiable, assurance, dan empathy, sedangkan sisanya $9,1 \%$ dijelaskan oleh variabel lain yang tidak diajukan dalam penelitian ini.

Diketahui t tabel sebesar 1,986 ( $\mathrm{df}=\mathrm{n}-\mathrm{k}-1=98-5-1=92$ ) dan dari hasil uji $\mathrm{t}$ diketahui variabel reliabilithy (X1) terdapat nilai sig $0,000<0,05$ dan $t_{\text {hitung }}$ $11,821,>t_{\text {tabel }} 1,986, \quad$ variabel responsiviness (X2) terdapat nilai sig $0,000<0,05$, dan $t_{\text {hitung }} 15,018,>t_{\text {tabel }}$ 1,986, variabel tangiable (X3) terdapat nilai sig $0,000<0,05$, dan $t_{\text {hitung }} 6,608$, > $\mathrm{t}_{\text {tabel }} 1,986$, variabel assurance (X4) terdapat nilai sig $0,002<0,05$, dan $t_{\text {hitung }}$ $3,147>t_{\text {tabel }} 1,986$, dan variabel empathy 
(X5) terdapat nilai sig 0,000 $<0,05$, dan $t_{\text {hitung }} 4,533>t_{\text {tabel }} 1,986$ Jadi dapat disimpulkan variabel bebas reliabilithy, responsiviness, tangiable, assurance, dan empathy mempunyai pengaruh yang signifikan dalam mempengaruhi kepuasan nasabah di Bank Danamon Sukodadi Lamongan.

Diketahui F tabel sebesar 2,31 ( $\mathrm{df}=\mathrm{n}-\mathrm{k}-1$ = 98-5-1=92), Dari hasil uji $\mathrm{F}$ menunjukan bahwa hasil signifikasi $0,000<0,05$ dan $\mathrm{F}$ hitung 194,656 > 2,31 , ini artinya variabel bebas yang terdiri dari reliabilithy, responsiviness, tangiable, assurance dan empathy berpengaruh secara simultan dalam mempengaruhi kepuasan nasabah di Bank Danamon Sukodadi Lamongan.

\section{PENUTUP}

\section{SIMPULAN}

1. Berdasarkan hasil penelitian dalam skripsi ini, maka dapat ditarik kesimpulan sebagai berikut : Diketahui t tabel sebesar $1,986(\mathrm{df}=\mathrm{n}-\mathrm{k}-1=98-5-1=92)$ dan dari hasil uji $t$ (parsial) diperoleh nilai $\mathrm{t}$ hitung reliabilithy (11,821), responsiviness ( 15,018$)$, tangiable $(6,068)$, assurance ( 3,147 ), empathy ( 4,533). Dengan nilai signifikasi kurang dari 0,05 yaitu secara berurutan masing-masing sebesar reliabilithy ( $0,000 \quad)$, responsiviness $(0,000)$, tangiable ( 0,000$)$, assurance $(0,002)$ dan empathy ( 0,000$)$ Hal ini berarti variabel bebas mempunyai pengaruh yang signifikan dalam mempengaruhi kepuasan nasabah di bank Danamon Sukodadi Lamongan.

2. Secara simultan variabel bebas (reliabilthy, responsiviness, tangiable, assurance, dan empathy ) mempunyai pengaruh yang signifikan terhadap kepuasan nasabah di Bank Danamon Sukodadi Lamongan. Hal ini bisa dilihat pada nilai $F$ tabel sebesar 2,31 ( $\mathrm{df}=\mathrm{n}-\mathrm{k}-1=$ 98-5-1=92), dengan nilai $\mathrm{F}$ hitung sebesar 194,656 dan tingkat signifikan kurang dari 0,05 yaitu sebesar 0,000 .

3. Dari hasil uji t diperoleh thitung reliabilithy $(11,821 \quad)$, responsiviness ( 15,018$)$, tangiable $(-6,608)$, assurance $(3,147)$, dan empathy $(4,533)$ Dengan demikian dapat ditarik kesimpulan bahwa variabel yang paling dominan mempengaruhi kepuasan nasabah di Bank Danamon Sukodadi Lamongan adalah variabel Responsiviness ( ketanggapan ) hal ini karena variabel responsiviness (X2) mempunyai nilai koefisien regresi dan nilai $t$ hitung tertinggi sebesar 2,062 dan 15,018.

\section{SARAN}

Berdasarkan dari hasil analisis data dan kesimpulan yang diperoleh, penulis dapat memberikan saran yang mungkin dapat digunakan sebagai pertimbangan oleh perusahaan dalam menentukan kebijakan perusahan, antara lain :

1. Disarankan kepada petugas customer service Bank Danamon Sukodadi Lamongan agar dapat memberikan pelayanan yang sebaik - baiknyadan memuaskan kepada nasabah dengan memperhatikan proses komunikasi dan sikap kepada nasabah, agar informasi yang diberikan tidak terjadi kesalah pahaman pada nasabah sehingga nasabah merasa puas dengan pelayanan yang diberikan. 
2. Dengan adanya penelitan ini, dapat memberikan suatu pengetahuan tentang betapa pentingnya Peran Customer Service dalam Meningkatkan Mutu Pelayanan dan Kepuasan Nasabah di Bank Danamon Sukodadi Lamongan.

\section{DAFTAR PUSTAKA}

Arikunto, Suharsimi. 2010. Prosedur

Penelitian. Cetakan ke-14. PT Rineka Cipta. Jakarta

Ismail. 2011. Manajemen Perbankaan.

Cetakan ke-2. Kencana Penada Media Group. Jakarta.

Kasmir. 2014. Manajemen

Perbankaan. Cetakan ke-12. PT

Raja Grafindo Persada, Jakarta.

Kasmir. 2010. Pemasaran

Bank.

Cetakan ke-4. Kencana Prenada

Media Group, Jakarta.

Masyhuri dan Zainuddin. 2011.

Metodologi Penelitian. Cetakan

ke-3. PT Refika Aditama,

Bandung.

Silaen Dan Yayak Heriyanto .2013.

Pengantar Statistika Social. In Media. Jakarta.

Sunyoto, Danang. 2013. Teori Kuisoner

Dan Analisis Data Untuk

Pemasaran Dan Perilaku

Konsumen. Graha Ilmu.

Yogyakarta

Sujarweni, Wiratna. 2014. Metodologi

Penelitian. Pustakabarupress.

Yogyakarta.

Wibowo, Rudi. 2012. Pengaruh Modal

Tenaga Kerja Bahan Baku Mesin

Terhadap Produksi Industri Kecil

Konveksi Desa Padurenan

Kecamatan Gebong Kabupaten

Kudus. Economics Development

Analysis Journal. ( Online ). Vol 1, No 2.

http://journal.unnes.ac.id/sju/index.p hp/edaj ),diaskes 01 Januari 2016 ).
Wijaya, Tony. 2011. Manajemen

Kualitas Jasa. Indeks. Jakarta. 
